\title{
DESAIN LEMARI ARSIPDI PT. BANK RAKYAT INDONESIA (BRI) PERSERO Tbk CABANG GOMBONGMENGGUNAKAN METODE QUALITY FUNCTIONDEPLOYMENT (QFD)
}

\author{
Akhmad Fauzy Nur Hidayako, Ida Betanursanti \\ Industrial Engineering Program \\ Muhammadiyah Technology High School of Kebumen \\ ejjafauzy@yahoo.co.id
}

\begin{abstract}
Filling cabinet designs are generally less attention to the aspects that will pose complaints. The cabinet must has a superiority to diminish indication musculoskeletal disorder, quality, display, and capacity for collection. The user want the filling cabinet product that safety, easily to use, comfortable. The purpose of research is designing cabinets and organized to the user's posture. Anthropometry data of filling cabinet taken fromemployees of BRI Gombong branch. After get the data, the researcher will process it use statistic test. Filling cabinet organize depend on employ needed with QFD method by engaging in designing to customer wishes to translate the matrix House of Quality (HOQ). Filling cabinet designed results in a safety, easy to use and comfortable is was of made wood, with oval shaped edges (not sharp). In the searching of archives, the users are recommended in standing with elbow height position about 122-123 cm. The filing cabinet added two ladders and moves them with hydraulic system to adjusting the height. It has 3 shelves, with grey color. There are 9 boxes, with each box has two shelves to receive more file. There are index label search on each box for easy search and organizing file.
\end{abstract}

Keywords: Filling cabinet, QFD, HOQ, Anthropometry

\section{PENDAHULUAN}

\section{A. Latar Belakang}

Dikenal ada dua macam industri yaitu industri yang menghasilkan barang dan industri yang menghasilkan jasa.Salah satu contoh industri jasa yaitu industri perbankan. Industri Perbankan pertama kali dibentuk dibawah naungan BUMN (Badan Usaha Milik Negara) dengan tujuan menghimpun atau mengumpulkan dana dari semua kalangan masyarakat dalam bentuk tabungan (simpanan), deposito, atau dengan memberi pinjaman kepada masyarakat dengan bentuk kredit untuk wirausaha.Semakin banyaknya minat masyarakat untuk melakukan transaksi, dalam melakukan pelayanan di industri perbankan haruslah efektif dan efisien karena masyarakat sudah mempercayai kredibilitas perbankan sehingga mengakibatkan meningkatnya jumlah nasabah yang datang.Hasil penelitian Hidayako (2015) menyatakan bahwa dalam pola pencarian berkas pada lemari menyebabkan tidak efisien waktu karena berkas berceceran dan juga letak berkas yang tidak teratur membuat pengguna menjadi kelelahan.Keluhan-keluhan itu andaikan tidak ditangani dapat menyebabkan gangguan musculoskeletaldisorder.Alat bantu sebuah pekerjaan sangatlah penting untuk membantu seorang pekerja dalam menjalankan tugasnyadan sebuah alat kerja haruslah sesuai dengan sistem atau postur dari para pemakai alat tersebut.

\section{B. Rumusan Masalah}

Membuat desain lemari yang dapat menampung berkas dan arsip secara terorganisir sesuai dengan ukuran postur tubuh karyawan bagian kearsipan di PT. Bank BRI Cabang Gombong.

\section{Batas an Masalah}

Perancangan lemari hanya sampai pada desain gambar tiga dimensi sesuai keinginan karyawan dengan menggunakan data anthropometri.Metode penelitian menggunakan Quality Function Deployment (QFD) dan diterapkan pada House of 
Quality (HOQ).Data anthropometri diolah secara statistik menggunakan uji validitas, reliabilitas, serta homogenitas menggunakan SPSS. Uji homogenitas hanya dilakukan pada nyaman dipandang yang meliputi warna dan bentuk.

\section{Tujuan}

Perancangan lemari yang bisa mengoorganisir arsip/berkas dengan desain sesuai postur tubuh pengguna lemari.

\section{LANDASAN TEORI}

\section{A. Kajian Pustaka}

Menurut Anggraeni Mutiara, Arie Desrianty, Yuniar (2013) yang meneliti rancangan meja dapur multifungsi menggunakan quality function deployment (QFD) menyatakan bahwa Rancangan produk yang berkualitas adalah rancangan yang dibuat berdasarkan fungsi dasar produk yang disesuaikan dengan kualitas, kapasitas dan penampilan yang memuaskan customer, serta nilai tambahan yang dapat menunjang dan menarik keinginan customer sepertigaya dan variansi warna pada produk. Keterbatasan lahan untuk membangun rumah menyebabkan ruang dapur terbatas.Untuk itu dibutuhkan meja dapur multifungsi untuk menampung peralatan dapur.Pengguna dapur menginginkan produk yang fleksibel dalam penggunaan dan penyimpanannya dengan melihat kenyamanan pengguna dapur.Meja dapur dirancang dengan beberapa fungsi menggunakan metode QFD yang merupakan sebuah metode perancangan yang langsung melibatkan customer.Meja dapur berguna untuk menaruh peralatan dan melakukan berbagai kegiatan. Selain itu meja dapur memiliki kelebihan dapat dibawa jika berpergian dan pada saat pindah rumah juga memiliki beberapa posisi dengan berbagai fungsi kegiatan.

Menurut Iswanti dan Erna Zakiyah (2015) yang meneliti tentang antropometri, dimensi dokumen rekam medis dan sistem penjajaran menyatakan bahwa Penelitian ini dilakukan untuk menganalisis desain rak file dari aspek antropometri di bagian filing di Rumah Sakit umum PKU Muhammadiyah Gubug Tahun 2013-2014 dengan metode observasi. Penelitian merupakan jenis penelitian deskriptif dengan pendekatan retrospektif. Variabel penelitian ini adalah Desain rak file, antropometri, dimensi dokumen rekam medis, sistem penjajaran. Hasil penelitian ini adalah ukuran rak file di Rumah Sakit Umum PKU Muhammadiyah Gubug : tinggi rak $230 \mathrm{~cm}$, panjang rak 240 $\mathrm{cm}$, lebar $60 \mathrm{~cm}$, dan tebal rata-rata dokumen rekam medis $0,3 \mathrm{~cm}$ sehingga mampu menyimpan 8000 dokumen rekam medis. Sedangkan secara ergonomis peneliti mendesain ulang rak tersebut mampu menyimpan 10.000 dokumen rekam medis karena adanya expansi $25 \%$ untuk sistem penyimpanan sentralisasi. Simpulan: Ukuran rak file yang sudah ada belum ergonomis.

Menurut Carolyn M Angelita (2014) yang meneliti tentang usulan perbaikan desain produk lemari praktis menggunakan quality function deployment (QFD) menyatakan bahwa sebagian besar produk atau alat yang diperuntukkan bagi manusia itu sendiri selama ini ternyata belum mampu membantu banyak dan belum dapat memenuhi kebutuhan orang banyak pada umumnya. Salah satu hal yang menyebabkannya adalah faktor perancangan dimana perancangan ini melibatkan segi ukuran, bahan, fungsi, estetika dan lain-lain yang berkenaan dengan penggunaannya.Masalah utama pada penelitian ini adalah bagaimana perancangan perbaikan produk lemari praktis menggunakan quality function deployment.Dalam penelitian ini produk yang dijadikan perbaikan merupakan produk lemari praktis yang telah ada terlebih dahulu.Penelitian yang dilakukan yaitu dengan studi pendahuluan, identifikasi masalah, penentuan tujuan, 
pengumpulan data, pengolahan data, analisis dan kesimpulan.Untuk memberikan gambaran perbaikan produk digunakan perangkat lunak AUTOCAD. Desain perbaikan produk lemari praktis yang berfokus pada konsumen yaitu dengan memperhatikan beban berat produk lemari praktis, tebal bahan baku, ukuran lemari praktis, ukuran cermin dan tempat meletakkan parfum, diameter roda dan diameter gagang dan kunci pintu.

\section{B. Anthropometri dan Quality Function Deployment (QFD)}

\section{a. Anthropometri}

Menurut Wignjosoebroto Sritomo (2003), dalam bukunya istilah anthropometri berasal dari " anthro " yang berarti manusia dan " metri " yang berarti ukuran. Secara definitif anthropometri dapat dinyatakan sebagai satu studi yang berkaitan dengan pengukuran dimensi tubuh manusia. Manusia pada dasarnya akan memiliki bentuk, ukuran (tinggi, lebar dsb.) berat dll. yang berbeda satu dengan yang lainnya. Anthropometri secara luas akan digunakan sebagai pertimbangan-pertimbangan ergonomis dalam proses perancangan produk maupun sistem kerja yang akan memerlukan interaksi manusia.
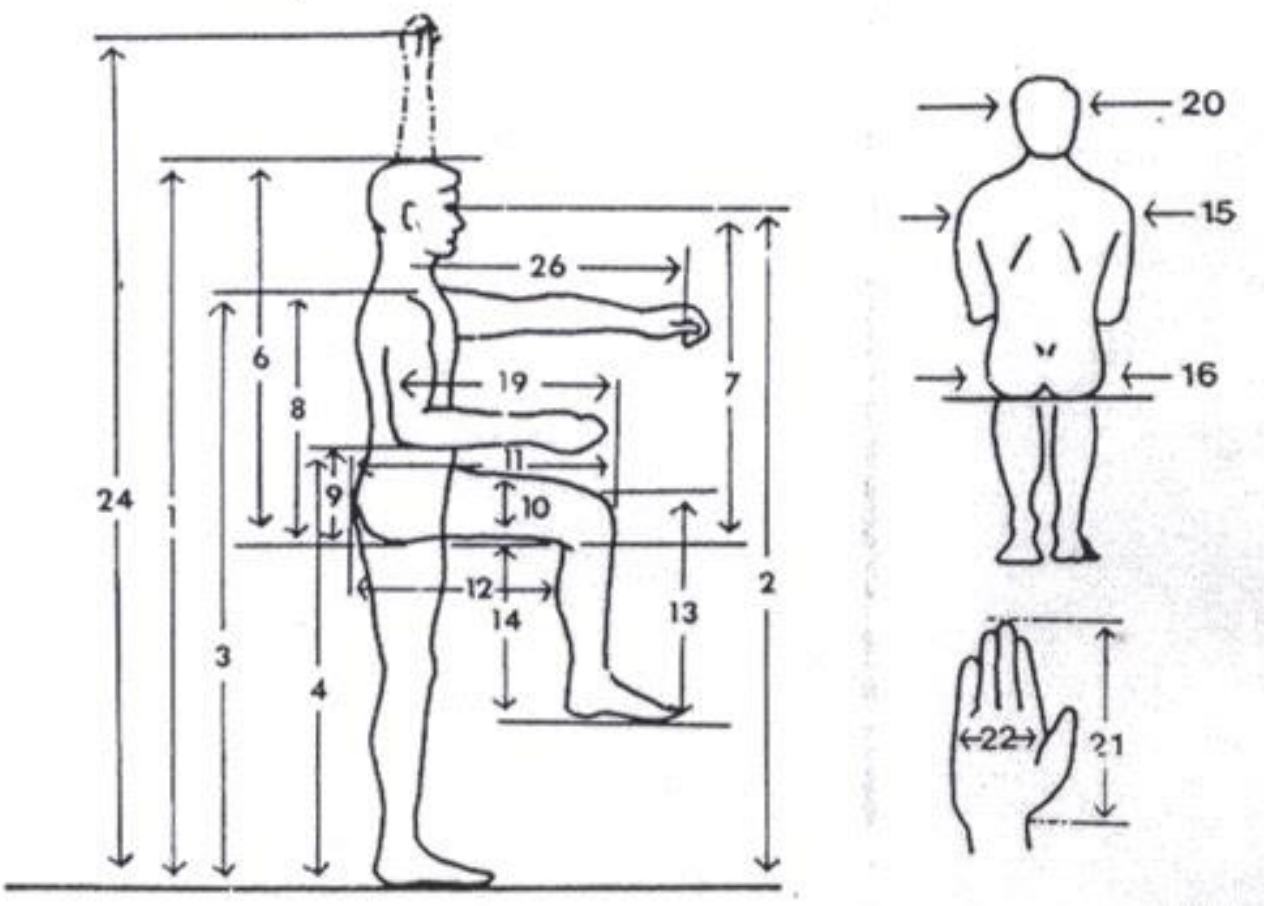

Gambar 1. Data anthropometri tubuh

(Sumber: Eko Nurmianto,2003)

Keterangan Pengukuran Anthropometri Gambar 1 :

a. Tinggi bahu dalam posisi berdiri tegak. (Gambar 1. Nomor 3)

b. Tinggi mata dalam posisi berdiri tegak. (Gambar 1. Nomor 2)

c. Tinggi jangkauan tangan dalam posisi berdiri tegak, diukur dari lantai sampai dengan telapak tangan yang terjangkau lurus keatas (vertikal). (Gambar 1. Nomor 24)

d. Dimensi tinggi tubuh dalam posisi tegak (dari lantai s/d ujung kepala). (Gambar 1. Nomor 1) 
e. Jarak jangkauan tangan yang terjulur kedepan diukur dari bahu sampai ujung jari tangan. (Gambar 1. Nomor 26)

f. Panjang siku yang diukur dari siku sampai dengan ujung jari-jari dalam posisi siku tegak lurus. (Gambar 1. Nomor 19)

g. Panjang paha yang diukur dari pantat sampai dengan ujung lutut. (Gambar 1. Nomor 11)

h. Tinggi siku dalam posisi berdiri tegak (siku tegak lurus). (Gambar 1. Nomor 4)

i. Tinggi lutut yang bisa diukur baik dalam posisi berdiri atau duduk. (Gambar 1 . Nomor 13).

j. Lebar telapak tangan (genggaman). (Gambar 1. Nomor 22)

k. Panjang paha yang diukur dari pantat sampai dengan bagian belakang dari lutut/betis. (Gambar 1. Nomor 12)

\begin{tabular}{c|c}
\multicolumn{2}{c}{ Tabel 1. Rumus baku persentil } \\
\hline Persentil & Perhitungan \\
\hline 1 - st & $\bar{X}-2,325$ бX \\
2.5 - th & $\bar{X}-1,96$ бX \\
5 - th & $\bar{X}-1,64$ бX \\
10 - th & $\bar{X}-1,28$ бX \\
50 - th & $\bar{X}$ \\
90 - th & $\bar{X}-1,28$ бX \\
95 - th & $\bar{X}-1,64$ бX \\
97 - th & $\bar{X}-1,96$ бX \\
99 - th & $\bar{X}-2,325$ бX \\
\hline
\end{tabular}

(Sumber : Sritomo Wignjosoebroto, 2003)

\section{b. QFD}

Menurut Revelle (1998) berpendapat bahwa QFD was created to help organization improve their ability to understand their customers needs as well as to effectively respond to those needs maksudnya QFD dibuat untuk membantu organisasi dalam meningkatkan kemampuannya dalam memahami kebutuhan costumer serta efektif menanggapi kebutuhan tersebut.

Tujuan QFD adalah menerjemahkan kriteria subjektif (costumer) tentang kualitas menjadi sesuatu yang lebih objektif, jadi QFD adalah proses perencanaan bukan alat untuk pemecahan masalah atau analisis.

Langkah pembuatan (fase) QFD dapat dikategorikan menjadi 4 tahapyaitu :

1. Perencanaan Produk

Tahap ini terdiri dari keinginan customer (costumer requirement) dan technicalresponses atau technicalrequirement yang diperoleh dari saran costumer hasil rekapitulasi pada e-Commerce.

2. Perencanaan Desain

Tahap ini terdiri dari technical requirements dan parts characteristics. Berkaitan dengan perancangan fungsi produk dalam hal ini berhubungan dengan ergonomi yang merupakan keilmuan dalam merancang pekerjaan, peralatan, dan mencangkup pula lingkungan tempat kerja yang nyaman bagi para perkerja (Sulianta, 2010)

3. Perancangan Proses (Process Planning)

Tahap ini terdiri dari part characteristics dan process characteristics. Merupakan proses aplikasi dan evaluasi saran costumer dan disesuaikan dengan sudut pandang ergonomi. 


\section{Perancangan Produksi (Production Planning)}

Tahap ini terdiri dari process characteristics dan production requirements.Dimana rancangan produk telah memiliki keterangan rancangan berupa gambar maupun karakteristik teknis.Dapat dilihat pada gambar 6 fase QFD.

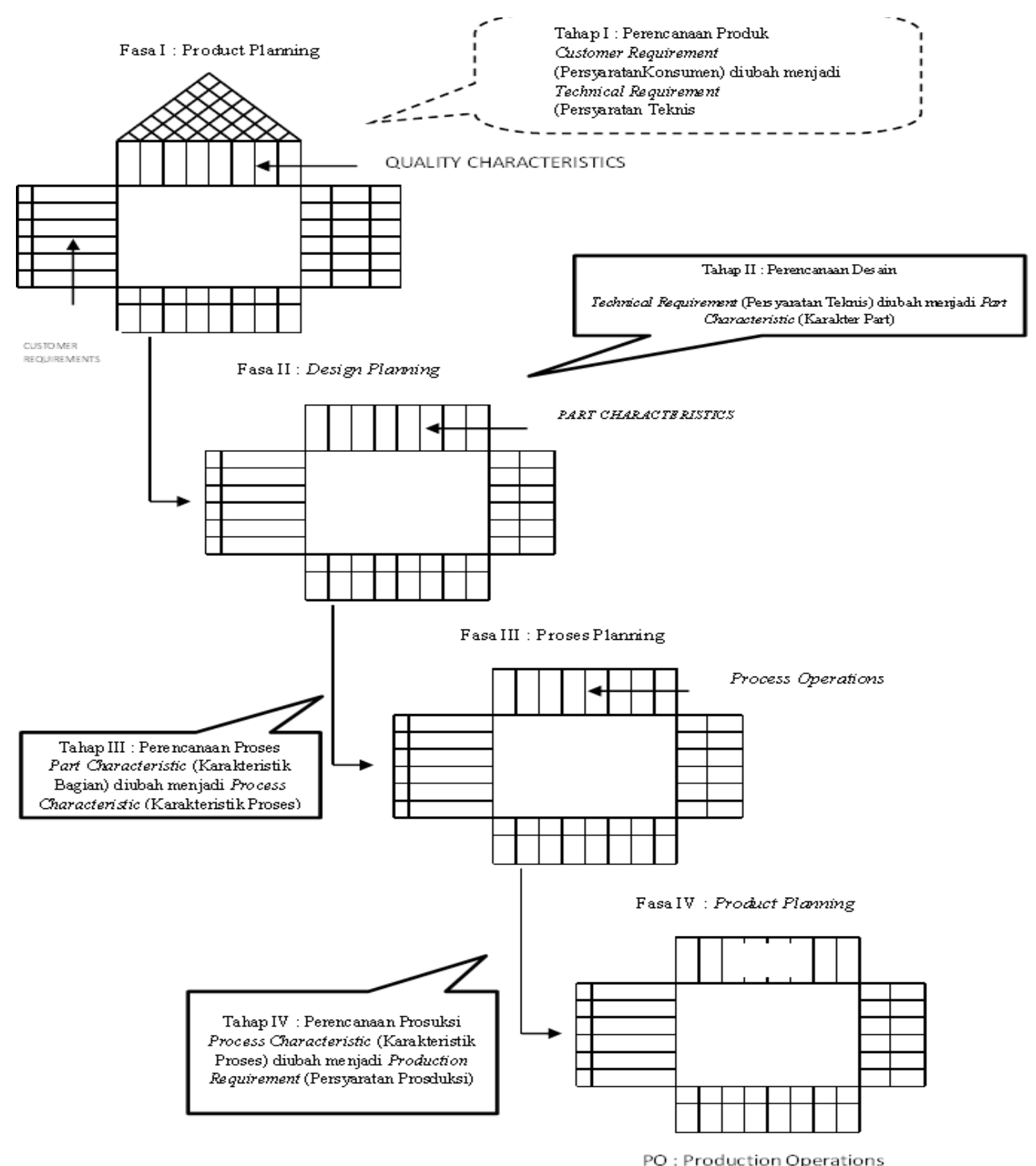

Gambar 6. Fase QFD

Sumber :Ihsan (2016)

\section{c. Uji Validitas dan Reliabilitas}

Uji validitas dilakukan untuk memastikan seberapa baik suatu instrument digunakan untuk mengukur konsep yang seharusnya diukur. Menurut Sugiyono (2010) untuk menguji validitas konstruk dilakukan dengan cara mengkorelasikan antara skor butir pertanyaan dengan skor total. 
Rumus yang digunakan untuk menguji validitas instrumen adalah korelasi bivarite karl pearson yaitu sebagai berikut :

$$
r=\frac{n \sum x y-\left(\sum x\right)\left(\sum y\right)}{\sqrt{\left\{n\left(\sum x^{2}-\left(\sum x\right)^{2}\right\}\left\{n\left(\sum y^{2}\right)-\left(\sum y\right)^{2}\right\}\right.}}
$$

Keterangan :

$\mathrm{rXY}=$ Koefisien korelasi $\mathrm{X}$ dan $\mathrm{Y}$, dua variabel yang dikorelasikan.

$\mathrm{X} \quad=$ Skor untuk pernyataan yang dipilih

$\mathrm{Y} \quad=$ Skor total

$\mathrm{n} \quad=$ Jumlah responden

Arikunto (2006) menyatakan "Reliabilitas menunjuk pada suatu pengertian bahwa sesuatu instrumen cukup dapat dipercaya untuk digunakan sebagai alat pengumpul data karena instrumen tersebut sudah baik".

Uji realibilitas dilakukan dengan rumus cronbach alpha sebagai berikut :

$$
r_{i}=\frac{k}{(k-1)}\left\{1-\frac{\sum s_{i}{ }^{2}}{S_{t^{2}}}\right\}
$$

Sumber : (Sugiyono, 2010)

Keterangan :

$$
\begin{array}{ll}
\mathrm{k} & =\text { mean kuadrat antara subyek } \\
\sum_{\mathrm{S}_{\mathrm{i}}{ }^{2}} & =\text { mean kuadrat kesalahan } \\
\mathrm{S}_{\mathrm{i}}{ }^{2} & =\text { varians item } \\
\mathrm{S}_{\mathrm{t}}{ }^{2} & =\text { varians total }
\end{array}
$$

\section{d. Uji Normalitas}

Menurut Imam Ghozali (2011, 160), uji normalitas bertujuan untuk menguji apakah dalam model regresi, variabel pengganggu atau residual memiliki distribusi normal, bila asumsi ini dilanggar maka uji statistik menjadi tidak valid untuk jumlah sampel kecil. Uji normalitas data dilakukan dengan uji Kolmogorov-Smirnov."Suatu data dinyatakan berdistribusi normal jika nilai Asymp Sig (2-tailed) hasil perhitungan Kolmogorov-Smirnovlebih besar dari $1 / 2 \alpha "$.

\section{e. Perhitungan Rumus Persentil}

i. Posisi P5 artinya nilai ketelitiannya sebesar $5 \%$ data yang berada di bawah nilai persentil dengan rumus sebagai berikut :

$$
p 5=\bar{X}-1.6456 X \text {. }
$$

ii. Posisi P50 artinya nilai ketelitiannya sebesar 50\% data yang berada di bawah nilai persentil dengan rumus sebagai berikut :

$P 50=X$

iii. Posisi P95 artinya nilai ketelitiannya sebesar $95 \%$ data yang berada di bawah nilai persentil dengan rumus sebagai berikut :

$$
P 95=\bar{X}+1.6456 X
$$

\section{f. Uji Homogenitas Varians Kruskall Wallis}

Uji Homogenitas bertujuan untuk mengetahui varians-varians dalam sampel homogen atau tidak. Tahapan perhitungannya adalah sebagai berikut :

i. Mencari nilai $\mathrm{F}$ dengan rumus, sebagai berikut :

$$
F=\frac{\text { Varians Besar }}{\text { Varians Kecil }}
$$

Sumber : (Sugiyono, 2010) 
ii. Menentukan derajat kebebasan

$\mathrm{dk}_{1}=\mathrm{n}_{1}-1 ; \mathrm{dk}_{2}=\mathrm{n}_{2-} 1$

iii. Menentukan nilai $\mathrm{F}_{\text {tabel }}$ pada taraf signifikansi $5 \%$ dari responden

iv. Penentuan keputusan dengan kriteria

Varians dianggap homogen apabila $F_{\text {hitung }}>F_{\text {tabel }}$. Pada taraf kepercayaan 0.95 dengan derajat kebebasan $\mathrm{dk}_{1}=\mathrm{n}_{1}-1$ dan $\mathrm{dk}_{2}=\mathrm{n}_{2}-1$, maka kedua varians dianggap sama (homogen) dan sebaliknya tidak homogen.

Hipotesis pengujian :

Ho : $\sigma 1^{2}=\sigma 2^{2}$ (varians data homogen)

Ha $: \sigma 1^{2} \neq \sigma 2^{2}$ (varians data tidak homogen)

Sumber : (Mantodang, 2016)

\section{METODE PENELITIAN}

Penelitian ini dilakukan diruang pengarsipan Bank BRI cabang Gombong, dengan jumlah pengguna lemari 15 orang.Pengambilan data dilakukan secara kualitatif dan kuantitatif.Data kualitatif diperoleh dari kuesioner terbuka, data yang diperoleh berupa keluhan-keluhan dari karyawan pengguna lemari.Data tersebut diolah menggunakan diagram fishbone untuk mengetahui keinginan dari karyawan (customer needs).Daftar keinginan tersebut dikelompokan menjadi tiga yaitu lemari aman, lemari mudah digunakan, dan lemari nyaman.Sedangkan data kuantitatif diperoleh dari pengukuran data anthropometri.Untuk melengkapi data statistik data ditambahkan 15 orang dari luar pengguna lemari dengan ukuran standar postur sesuai dengan kriteria rekrutmen karyawan PT. BRI. Data kualitatif dan kuantitatif yang diperoleh, diolah secara statistik dengan menggunakan uji validitas, reliabilitas, dan uji normalitas untuk data kuantitatif serta pencarian persentil yang cocok untuk digunakan dalam desain lemari. Setelah data-data lengkap diolah menggunakan metode Quality Function Deployment (QFD) untuk diterjemahkan pada House of Quality (HOQ).Lalu dibuat desain lemari tiga dimensi yang sesuai dengan postur tubuh karyawan bagian pengarsipan.Setelah desain jadi, desain diuji menggunakan uji homogenitas untuk mengetahui nilai kepuasan lemari setelah didesain ulang.

\section{HASIL DAN PEMBAHASAN}

\section{A. Deskripsi Data Penelitian dan Subjek Penelitian}

Penelitian ini dilakukan di PT. Bank Rakyat Indonesia (BRI) yang beralamat di PT. Bank Rakyat Indonesia Jl. Raya Yos Sudarso Timur, No. 208, Gombong, Kebumen, Indonesia.Konsentrasi penelitian di bagian pengarsipan.Penelitian ini bertujuan untuk mendesain sebuah lemari sesuai dengan anthropometri postur tubuh karyawan. Penelitian ini menggunakan tools diagram fish bone, yang diterapkan pada metode QFD (Quality Function Deployment) dan uji statistik untuk anthropometri dengan jumlah responden 15 karyawan di bagian pengarsipan dan ditambahkan dari umum 15 sampel yang sesuai dengan kriteria karyawan.

a. Pengumpulan data penelitian ini meliputi :

1. Identifikasi customer needs (validitas, Reliabilitas)

2. Penyusunan HOQ (House Of Quality)

- Pengukuran data anthropometri menggunakan Uji Normalitas.

- Penentuan kualitas lemari

- Perencanaan produk lemari

- Proses produksi

3. Desain lemari (Gambar dan Spesifikasi)

4. Validasi menggunakan homogenitas varians 
Tabel 2. Hasil Atribut Needs

\begin{tabular}{c|l|c}
\hline No & \multicolumn{1}{|c|}{ Atribut Kuesioner } & Atribut Needs \\
\hline 1 & Bahan Kurang Awet & \multirow{2}{*}{ Lemari Aman } \\
\hline 2 & Posisi Pengambilan Tidak Statis & \multirow{2}{*}{ Lemari Mudah } \\
\hline 3 & Berkas Berantakan & Digunakan \\
\hline 4 & Berkas Tidak Terorganisir & \\
\hline 5 & Pencarian Berkas Acak & Lemari Nyaman \\
\hline 6 & Pencarian Berkas Sulit & \\
\hline 7 & Lemari Jelek &
\end{tabular}

Tabel 3. Hasil Uji Validasi Atribut Needs

\begin{tabular}{c|l|c|c|c}
\hline No & Kebutuhan Customer (Needs) & $\begin{array}{c}\text { Nilai } \mathrm{r} \\
\text { hitung }\end{array}$ & $\begin{array}{c}\text { Nilai } \mathrm{r} \\
\text { tabel }\end{array}$ & Keterangan \\
\hline 1 & Lemari Aman & 0.595 & 0.514 & Valid \\
2 & Lemari Mudah Digunakan & 0.595 & 0.514 & Valid \\
3 & lemari Nyaman & 0.711 & 0.514 & Valid \\
\hline
\end{tabular}

Dari hasil uji validitas sebagaimana tercantum di tabel tiga diatas menunjukkan bahwa nilai rhitung > rtabel.Dengan demikian dapat disimpulkan bahwa instrumen dari daftar keinginan customer dinyatakan valid.

Tabel 4. Uji Reliabilitas Atribut Needs

\section{Reliability Statistics}

\begin{tabular}{|c|r|}
\hline $\begin{array}{c}\text { Cronbach's } \\
\text { Alpha }\end{array}$ & N of Items \\
\hline .722 & 4 \\
\hline
\end{tabular}

Dari hasil uji reliabilitas sebagaimana tercantum di atas menunjukkan nilai Alpha 0.722 untuk keinginan customer.Dengan demikian dapat disimpulkan bahwa instrumen dalam penelitian ini dinyatakan reliable karena nilai alpha lebih dari 0,7. 
Tabel 5. Uji Normalitas Data Anthropometri

\begin{tabular}{|c|c|c|c|c|c|c|c|c|c|c|c|c|c|}
\hline \multicolumn{14}{|c|}{ One-Sample Kolmogorov-Smirnov Test } \\
\hline & & $\begin{array}{l}\text { Tinggi bahu } \\
\text { dalam posisi } \\
\text { berdiri tegak }\end{array}$ & $\begin{array}{l}\text { Tinggi mata } \\
\text { dalam posisi } \\
\text { berdiri tegak }\end{array}$ & $\begin{array}{c}\text { Tinggi } \\
\text { jangkauan } \\
\text { tangan dalam } \\
\text { posisi berdiri } \\
\text { tegak, diukur } \\
\text { dari lantai } \\
\text { sampai } \\
\text { dengan } \\
\text { telapak } \\
\text { tangan yang } \\
\text { terjangkkau } \\
\text { lurus keatas } \\
\text { (vertikal) }\end{array}$ & $\begin{array}{c}\text { Dimensi } \\
\text { tinggi tubuhn } \\
\text { dalam posisi } \\
\text { tegak (dari } \\
\text { lantai s/d } \\
\text { ujung kepala) }\end{array}$ & $\begin{array}{c}\text { Jarak } \\
\text { jangkauan } \\
\text { tangan yang } \\
\text { teriulur } \\
\text { kedepan } \\
\text { dilukur dari } \\
\text { bahu sampai } \\
\text { ujung jari } \\
\text { tangan }\end{array}$ & $\begin{array}{l}\text { Panjang siku } \\
\text { yang diukur } \\
\text { dari siku } \\
\text { sampai } \\
\text { dengan ujung } \\
\text { jari.jari dalam } \\
\text { posisi siku } \\
\text { tegak lurus }\end{array}$ & $\begin{array}{l}\text { Panjang paha } \\
\text { yang diukur } \\
\text { dari pantat } \\
\text { sampai } \\
\text { dengan ujung } \\
\text { lutut }\end{array}$ & $\begin{array}{c}\text { Tinggi siku } \\
\text { dalam posisi } \\
\text { berdiri tegak } \\
\text { (siku tegak } \\
\text { lurus) }\end{array}$ & $\begin{array}{l}\text { Tinggi lutut } \\
\text { yang bisa } \\
\text { diukur baik } \\
\text { dalam posisi } \\
\text { berdiri atau } \\
\text { duduk }\end{array}$ & $\begin{array}{l}\text { Lebar telapak } \\
\text { tangan } \\
\text { (genggaman) }\end{array}$ & $\begin{array}{l}\text { Panjang pana } \\
\text { yang diukur } \\
\text { dari pantat } \\
\text { sampai } \\
\text { dengan } \\
\text { bagian } \\
\text { belakang dari } \\
\text { lutudbetis }\end{array}$ & Total \\
\hline$N$ & & 30 & 30 & 30 & 30 & 30 & 30 & 30 & 30 & 30 & 30 & 30 & 30 \\
\hline Normal Parameters & Mean & 144.00 & 164.07 & 189.77 & 166.43 & 70.87 & 47.33 & 45.67 & 109.57 & 50.20 & 5.50 & 51.63 & 1045.03 \\
\hline & Std. Deviation & 4.347 & 5.546 & 5.456 & 8.378 & 4.622 & 2.006 & 2.139 & 7.060 & 5.108 & .509 & 3.557 & 37.510 \\
\hline Most Extreme Differences & Absolute & .155 & .136 & .223 & .181 & .120 & .164 & .178 & .185 & .146 & .337 & .146 & .105 \\
\hline & Positive & .155 & .106 & .122 & .181 & .120 & .147 & .138 & .185 & .146 & .337 & .146 & .084 \\
\hline & Negative & .155 & -136 & .223 & .163 & .114 & .164 & .178 & .142 & .142 & .337 & .141 & .105 \\
\hline Kolmogorov-Smirnov Z & & .849 & .747 & 1.223 & .991 & .660 & .896 & .973 & 1.012 & .798 & 1.847 & .802 & .574 \\
\hline Asymp. Sig. (2-tailed) & & .467 & .633 & .100 & .280 & .776 & .398 & .300 & .257 & .548 & .002 & .541 & .897 \\
\hline
\end{tabular}

Uji Normalitas dilakukan untuk mengetahui data yang telah diukur layak untuk diolah lebih lanjut atau tidak. Berdasarkan nilai output Asymp Sig pada tabel limadi atas diketahui bahwa nilai signifikan dari masing-masing atribut $>0.05$, sehingga data yang diuji dinyatakan berdistribusi normal.

Tabel 6. Hasil Uji Validasi Data Anthropometri

\begin{tabular}{|c|l|c|c|c|}
\hline No & \multicolumn{1}{|c|}{ Anthropometri } & $\begin{array}{c}\text { Nilai } \\
\text { Hitung }\end{array}$ & $\begin{array}{c}\text { Nilai } \\
\text { rtabel }\end{array}$ & Keterangan \\
\hline 1 & Tinggi bahu dalam posisi berdiri tegak & 0.795 & 0.361 & Valid \\
\hline 2 & Tinggi mata dalam posisi berdiri tegak & 0.818 & 0.361 & Valid \\
\hline 3 & Tinggi jangkauan tangan dalam posisi & & 0.361 & Valid \\
\hline & berdiri tegak, diukur dari lantai sampai & 0.761 & 0.361 & Valid \\
& dengan telapak tangan yang terjangkau lurus keatas (vertikal) & & 0.361 & Valid \\
\hline 4 & Dimensi tinggi tubuh dalam posisi tegak (dari lantai s/d ujung kepala) & 0.818 & 0.361 & Valid \\
\hline 5 & Jarak jangkauan tangan yang terjulur kedepan diukur dari bahu sampai ujung jari tangan & 0.774 & 0.361 & Valid \\
\hline & Panjang siku yang diukur dari siku sampai dengan ujung jari-jari dalam posisi siku tegak & & & \\
& lurus & 0.767 & 0.361 & Valid \\
\hline 7 & Panjang paha yang diukur dari pantat sampai dengan ujung lutut & 0.703 & 0.361 & Valid \\
\hline 8 & Tinggi siku dalam posisi berdiri tegak (siku tegak lurus) & 0.756 & 0.361 & Valid \\
\hline 9 & Tinggi lutut yang bisa diukur baik dalam posisi berdiri atau duduk & 0.800 & 0.361 & Valid \\
\hline 10 & Lebar telapak tangan (genggaman) & 0.534 & 0.361 & Valid \\
\hline 11 & Panjang paha yang diukur dari pantat sampai dengan bagian belakang dari lutut/betis & 0.619 & 0.361 & Valid \\
\hline
\end{tabular}

Dari hasil uji validitas di atas menunjukkan bahwa nilai $\mathrm{r}$ hitung $>\mathrm{r}$ tabel.Dengan demikian dapat disimpulkan bahwa instrumen dari data anthropometri dinyatakan valid. 
Tabel 7. Hasil Uji Reliabilitas Data Anthropometri

Reliability Statistics

\begin{tabular}{|r|r|}
\hline $\begin{array}{c}\text { Cronbach's } \\
\text { Alpha }\end{array}$ & $\begin{array}{c}\text { N of } \\
\text { Items }\end{array}$ \\
\hline .766 & 12 \\
\hline
\end{tabular}

Dari hasil Uji Reliabilitas data anthropometri pada tabel 7 menunjukkan nilai Alphasebesar0.766 untuk data anthropometri.Dengan demikian dapat disimpulkan bahwa instrumen dalam penelitian ini reliable karena nilai alpha lebih dari 0,7.

Tabel 8. Data persentil yang akan digunakan untuk desain

Statistics

\begin{tabular}{|c|c|c|c|c|c|c|c|c|c|c|c|c|c|}
\hline & & $\begin{array}{l}\text { Tinggi bahu } \\
\text { dalam posisi } \\
\text { berdiri tegak }\end{array}$ & $\begin{array}{l}\text { Tinggi mata } \\
\text { dalam posisi } \\
\text { berdiri tegak }\end{array}$ & $\begin{array}{c}\text { Tinggi } \\
\text { jangkauan } \\
\text { tangan dalam } \\
\text { posisi berdiri } \\
\text { tegak, diukur } \\
\text { dari lantai } \\
\text { sampai } \\
\text { dengan } \\
\text { telapak } \\
\text { tangan yang } \\
\text { terjangkau } \\
\text { lurus keatas } \\
\text { (vertikal) }\end{array}$ & $\begin{array}{c}\text { Dimensi } \\
\text { tinggi tubuh } \\
\text { dalam posisi } \\
\text { tegak (dari } \\
\text { lantai s/d } \\
\text { ujung kepala) }\end{array}$ & $\begin{array}{c}\text { Jarak } \\
\text { jangkauan } \\
\text { tangan yang } \\
\text { terjulur } \\
\text { kedepan } \\
\text { diukur dari } \\
\text { bahu sampai } \\
\text { ujung jari } \\
\text { tangan }\end{array}$ & $\begin{array}{l}\text { Panjang siku } \\
\text { yang diukur } \\
\text { dari siku } \\
\text { sampai } \\
\text { dengan ujung } \\
\text { jari-jari dalam } \\
\text { posisi siku } \\
\text { tegak lurus }\end{array}$ & $\begin{array}{l}\text { Panjang paha } \\
\text { yang diukur } \\
\text { dari pantat } \\
\text { sampai } \\
\text { dengan ujung } \\
\text { lutut }\end{array}$ & $\begin{array}{c}\text { Tinggi siku } \\
\text { dalam posisi } \\
\text { berdiri tegak } \\
\text { (siku tegak } \\
\text { lurus) }\end{array}$ & $\begin{array}{l}\text { Tinggi lutut } \\
\text { yang bisa } \\
\text { diukur baik } \\
\text { dalam posisi } \\
\text { berdiri atau } \\
\text { duduk }\end{array}$ & $\begin{array}{l}\text { Lebar telapak } \\
\text { tangan } \\
\text { (genggaman) }\end{array}$ & $\begin{array}{l}\text { Panjang paha } \\
\text { yang diukur } \\
\text { dari pantat } \\
\text { sampai } \\
\text { dengan } \\
\text { bagian } \\
\text { belakang dari } \\
\text { lututbetis }\end{array}$ & Total \\
\hline \multirow[t]{2}{*}{ N } & Valid & 30 & 30 & 30 & 30 & 30 & 30 & 30 & 30 & 30 & 30 & 30 & 30 \\
\hline & Missing & 0 & 0 & 0 & 0 & 0 & 0 & 0 & 0 & 0 & 0 & 0 & 0 \\
\hline Percentiles & 95 & 150.00 & 171.00 & 197.35 & 180.00 & 77.00 & 50.00 & 48.00 & 122.45 & 58.00 & 6.00 & 58.45 & 1110.60 \\
\hline
\end{tabular}

Olah data persentil yang digunakan yaitu persentil 95 seperti tertera pada tabel 8, dengan alasan menggunakan persentil besar diharapkan semua pengguna lemari dapat menggunakan secara efisien. 


\section{B. Rumah House of Quality (HOQ)}

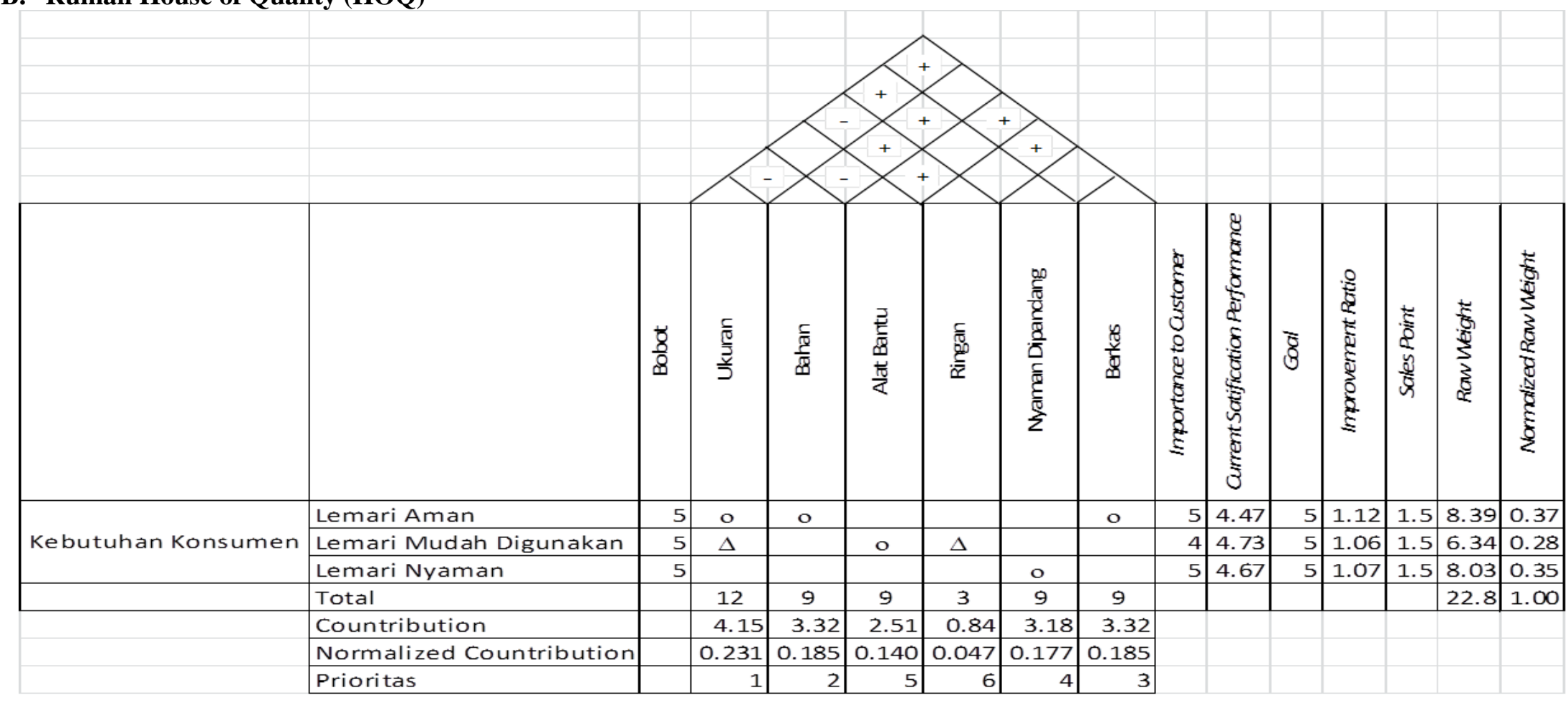

Gambar 3.House of Quality (HOQ) I Penentuan Kualitas Lemari

Keterangan :
$\mathrm{O}=$ Pengaruh kuat skor 9
$++=$ Korelasi positif dan kuat
$\Delta=$ Pengaruh sedang skor 3
$+=$ Korelasi positif tapi kurang kuat
$\mathrm{x}=$ Pengaruh lemah 1
- $=$ Korelasi negatif 


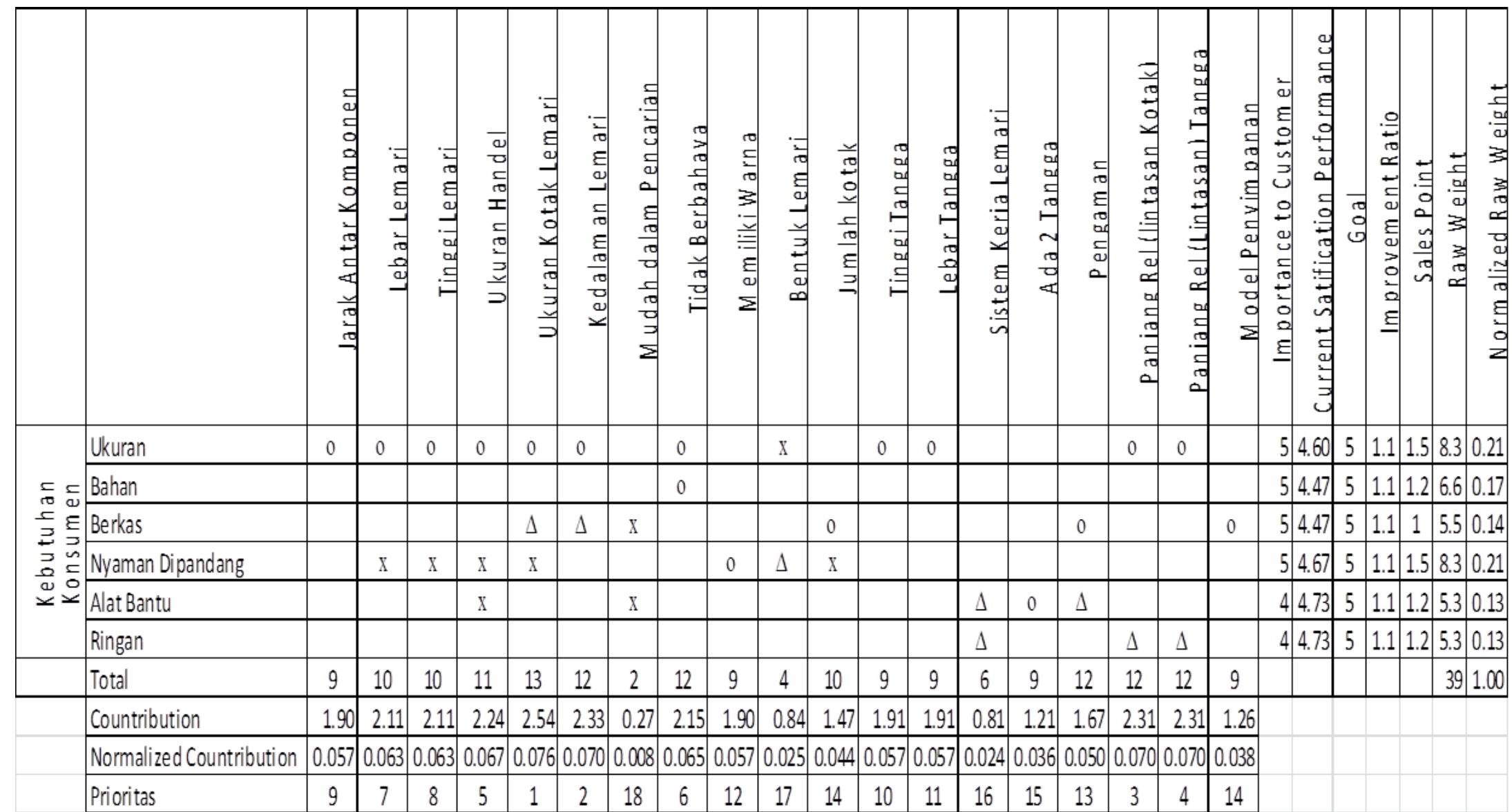

Keterangan :

Gambar 4. House of Quality (HOQ) II Perencanaan Produk Lemari
$\mathrm{O}=$ Pengaruh kuat skor 9
$++=$ Korelasi positif dan kuat
$\Delta=$ Pengaruh sedang skor 3
$+=$ Korelasi positif tapi kurang kuat
$\mathrm{x}$ = Pengaruh lemah 1
- $=$ Korelasi negatif 


\begin{tabular}{|c|c|c|c|c|c|c|c|c|c|c|c|c|c|c|c|c|c|c|c|c|c|c|c|c|c|c|c|}
\hline & & 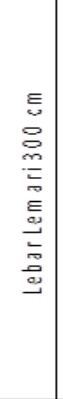 & 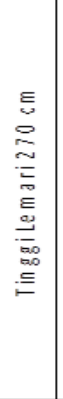 & 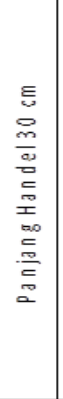 & 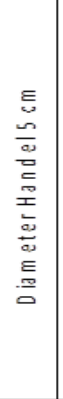 & 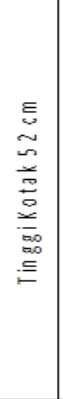 & 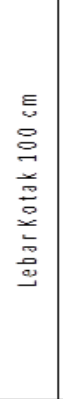 & 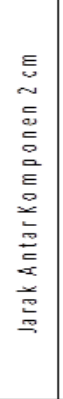 & 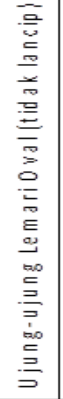 & 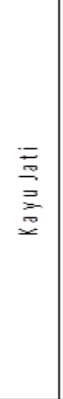 & 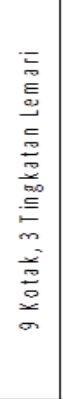 & 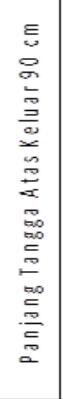 & 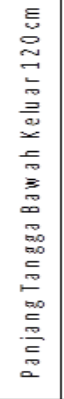 & 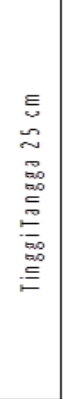 & 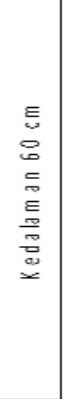 & 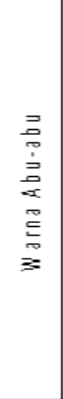 & 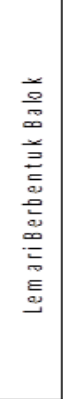 & 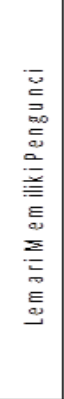 & 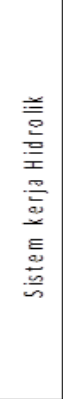 & 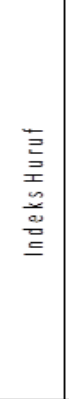 & 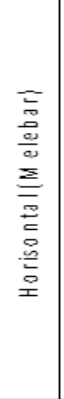 & 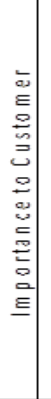 & 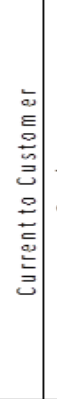 & & 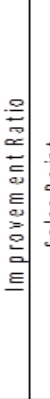 & & 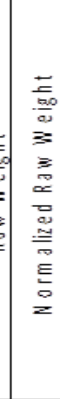 \\
\hline \multirow{23}{*}{ 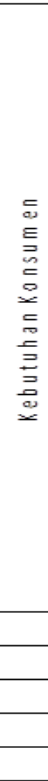 } & Ukuran Kotak Lemari & & & & & 0 & 0 & & & & & & & & & & & & & & & 4 & \begin{tabular}{l|l}
4.58 \\
\end{tabular} & 5 & 1.1 .1$. & $\begin{array}{l}.56 .5 \\
6.5\end{array}$ & \begin{tabular}{l|l}
5 & 0.06 \\
\end{tabular} \\
\hline & Kedalaman Lemari & & & & & & & & & & & & & & 0 & & & & & & & 5 & 4.54 & 5 & 1.1 .1$. & $\begin{array}{l}58.2 \\
8.2\end{array}$ & \begin{tabular}{c|c}
6 & 0.07 \\
\end{tabular} \\
\hline & \begin{tabular}{|l} 
Panjang Rel (lintasan Kotak) \\
\end{tabular} & & & & & & & & & & & & & & 0 & & & & & & & 5 & \begin{tabular}{l|l}
4.67 \\
\end{tabular} & 3 & 0.61. & 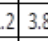 & \begin{tabular}{l|l}
5 & 0.03 \\
\end{tabular} \\
\hline & Panjang Rel (Lintasan) Tangga & & & & & & & & & & & 0 & 0 & & & & & & & & & 5 & 4.70 & 3 & \begin{tabular}{l|l}
0.61. \\
\end{tabular} & 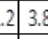 & \begin{tabular}{l|l}
3 & 0.03 \\
\end{tabular} \\
\hline & Ukuran Handel & & & 0 & 0 & & & & & & & & & & & & & & & & & 5 & \begin{tabular}{l|l}
4.67 \\
\end{tabular} & 3 & \begin{tabular}{l|l}
0.61. &.
\end{tabular} & \begin{tabular}{c|c|c|c|}
.2 & 3.8 \\
\end{tabular} & \begin{tabular}{l|l}
5 & 0.03 \\
\end{tabular} \\
\hline & Tidak Berbahaya & & & & & & & & 0 & $\Delta$ & & & & & & & & & & & & 5 & 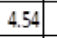 & 5 & 1.1 .1$. & $\begin{array}{l}.5 \\
8.2\end{array}$ & \begin{tabular}{l|l}
6 & 0.07 \\
\end{tabular} \\
\hline & Lebar Lemari & 0 & & & & & $\Delta$ & & & & & & & & & & & & & & & 5 & 4.64 & 5 & 1.1 .1$. & .58 .0 & \begin{tabular}{l|l}
8 & 0.07 \\
\end{tabular} \\
\hline & Tinggi Lemari & & 0 & & & $\Delta$ & & & & & & & & & & & & & & & & 5 & 4.64 & 5 & 1.11. & .58 .0 & \begin{tabular}{l|l}
8 & 0.07 \\
\end{tabular} \\
\hline & \begin{tabular}{|l} 
Jarak Antar Komponen \\
\end{tabular} & & & & & & 0 & & & & $\Delta$ & & & & & & & & & & & 5 & $4.60 \mid$ & 3 & $\begin{array}{ll}0.71 . \\
\end{array}$ & \begin{tabular}{l|l}
2 & 3.9 \\
\end{tabular} & \begin{tabular}{l|l}
1 & 0.03 \\
\end{tabular} \\
\hline & Tinggi Tangga & & & & & & & & & & & & & 0 & & & & & & & & 5 & 4.60 & 3 & $\begin{array}{ll}0.71 . \\
\end{array}$ & $\begin{array}{l}.23 .9 \\
3.9\end{array}$ & \begin{tabular}{l|l}
1 & 0.03 \\
\end{tabular} \\
\hline & \begin{tabular}{|l} 
Lebar Tangga \\
\end{tabular} & 0 & & & & & & & & & & & & & & & & & & & & 5 & $4.60 \mid$ & 3 & 0.71. & $\begin{array}{l}.23 .9 \\
3.9\end{array}$ & \begin{tabular}{l|l}
1 & 0.03 \\
\end{tabular} \\
\hline & Pengaman & & & & & & & & & & & & & & & & & 0 & & & & 5 & 4.60 & 4 & 0.91. & $\begin{array}{l}.25 .2 \\
.250 .20\end{array}$ & \begin{tabular}{l|l}
2 & 0.05 \\
\end{tabular} \\
\hline & Memiliki Warna & & & & & & & & & & & & & & & 0 & & & & & & 5 & \begin{tabular}{l|l}
4.67 \\
\end{tabular} & 5 & 1.11. & $\begin{array}{l}.58 .0 \\
8.0\end{array}$ & \begin{tabular}{l|l}
3 & 0.07 \\
\end{tabular} \\
\hline & Jumlah Kotak & & & & & 0 & 0 & $\Delta$ & & & 0 & & & & & & & & & & & 5 & 4.57 & 4 & $\begin{array}{ll}0.91 . \\
\end{array}$ & .56 .5 & \begin{tabular}{l|l}
6 & 0.06 \\
\end{tabular} \\
\hline & Model Penyimpanan & & & & & & & & & & & & & & & & & & & & 0 & 5 & 4.47 & 5 & 1.1 .1$. & $\begin{array}{ll}.05 .5 \\
\end{array}$ & \begin{tabular}{c|c}
9 & 0.05 \\
\end{tabular} \\
\hline & \begin{tabular}{|l|} 
Ada 2 Tangga \\
\end{tabular} & & & & & & & & & & $\Delta$ & & & & & & & & $\Delta$ & & & 5 & \begin{tabular}{l|l}
4.67 \\
\end{tabular} & 3 & \begin{tabular}{l|l}
0.61. \\
\end{tabular} & $\begin{array}{l}.2 \\
2.8 \\
\end{array}$ & \begin{tabular}{l|l}
5 & 0.03 \\
\end{tabular} \\
\hline & Sistem Kejja Lemari & & & & & & & & & & & & & & & & & & 0 & & & 5 & \begin{tabular}{l|l}
4.69 \\
\end{tabular} & 5 & 1.1 .1$. & 5 & \begin{tabular}{l|l}
8 & 0.07 \\
\end{tabular} \\
\hline & Bentuk Lemari & & & & & & & & & & & & & & & & 0 & & & & & 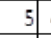 & 4.64 & 5 & 1.11. & .26. & $\begin{array}{ll}7 & 0.06 \\
\end{array}$ \\
\hline & Mudah Dalam Pencarian & & & & & & & & & & & & & & & & & & & 0 & & 5 & $4.60 \mid$ & 5 & 1.1 .1$. & $\begin{array}{c}58 . \\
8 .\end{array}$ & \begin{tabular}{c|c}
5 & 0.07 \\
\end{tabular} \\
\hline & Total & 18 & 9 & 9 & 9 & 21 & 30 & 3 & 9 & 3 & 15 & 9 & 9 & 9 & 18 & 9 & 9 & 9 & 12 & 9 & 9 & & & & 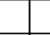 & 1. & \begin{tabular}{l|l}
4 & 1.00 \\
4
\end{tabular} \\
\hline & Countribution & 0.94 & 0.64 & 0.30 & 0.30 & 1.67 & 1.55 & 0.17 & 0.65 & 0.22 & 0.72 & 0.30 & 0.30 & 0.31 & 0.95 & 0.63 & 0.51 & 0.41 & 0.73 & 0.64 & 0.44 & & & & & & \\
\hline & Nomalized Countribution & 0.076 & 0.051 & 0.024 & 0.024 & 0.135 & 0.125 & 0.014 & 0.052 & 0.017 & 0.058 & 0.024 & 0.024 & 0.025 & 0.077 & 0.051 & 0.041 & 0.033 & 0.059 & 0.052 & 0.036 & & & & & & \\
\hline & Prioritas & 4 & 10 & 17 & 18 & 1 & 2 & 20 & 8 & 19 & 6 & 16 & 15 & 14 & 3 & 9 & 11 & 13 & 5 & 7 & 12 & & & & & & \\
\hline
\end{tabular}

Keterangan :

\section{Gambar 5.House of Quality (HOQ) III Proses Produksi}

$\mathrm{O}=$ Pengaruh kuat skor $9++=$ Korelasi positif dan kuat

$\Delta=$ Pengaruh sedang skor $3 \quad+=$ Korelasi positif tapi kurang kuat

$\mathrm{x}=$ Pengaruh lemah $1 \quad-\quad=$ Korelasi negatif 
Tabel 9. Hasil Uji Homogenitas

\begin{tabular}{|l|r|r|r|}
\multicolumn{4}{|c|}{ Test Statistics $^{\mathrm{a}, \mathrm{b}}$} \\
& Bentuk & Warna & $\begin{array}{r}\text { Jumlah Kotak } \\
\text { dan Tingkatan }\end{array}$ \\
\hline Chi-Square & 1.158 & .563 & 3.375 \\
df & 1 & 1 & 1 \\
Asymp. Sig. & .282 & .453 & .066 \\
\hline
\end{tabular}
a. Kruskal Wallis Test
b. Grouping Variable: Nyaman Di Pandang

Dari uji homogenitas pada tabel 9 diatas menyatakan bahwa hasil dari nyaman dipandang meliputi bentuk dan warna. Bentuk memiliki nilai sig 0.866 dan warna memiliki nilai sig 0.435 dengan kata lain bahwa setiap faktor yang mempunyai nilai $>0.05$ sesuai dengan dasar dari pengambilan keputusan uji beda homogenitas.Sehingga dapat disimpulkan bahwa $\mathrm{H}_{0}$ ditolak dan $\mathrm{H}_{1}$ diterima.Yang mempunyai arti bahwa pengguna mempunyai nilai kepuasan kepada lemari yang didesain ulang.

\section{A. Hasil Gambar Desain Lemari}

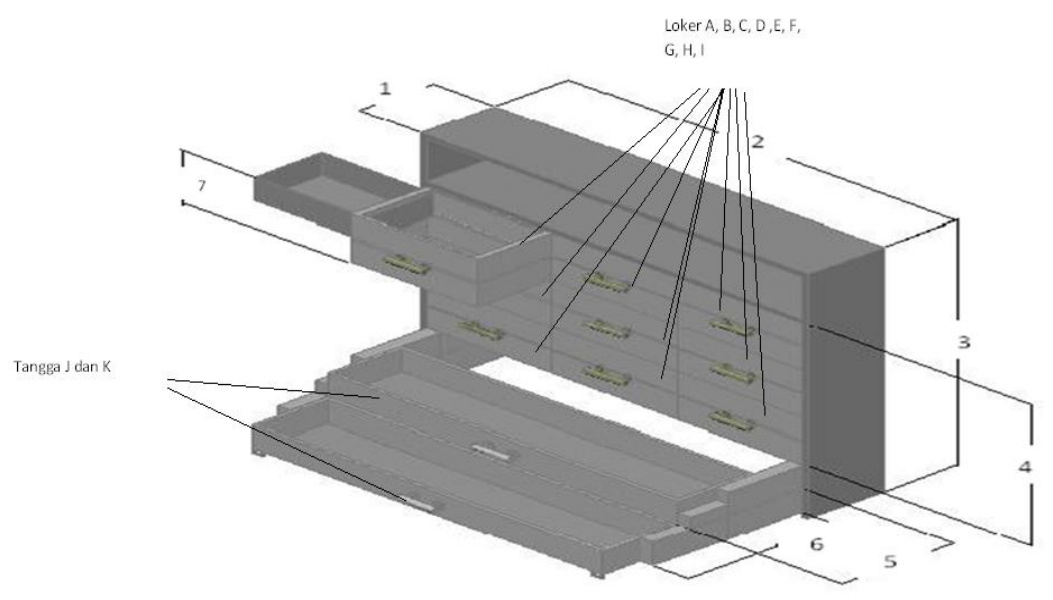

Gambar 17. Gambar Lemari Keseluruhan

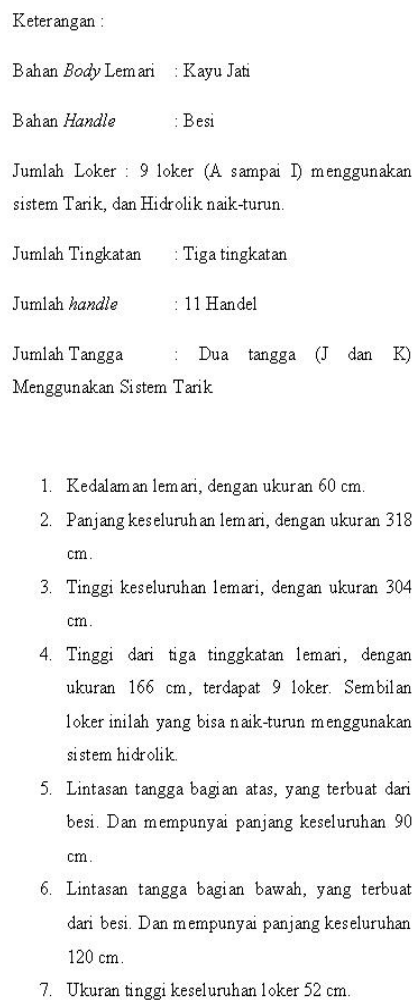

3. Tinggi keseluruhan lemari, dengan ukuran 304 $\mathrm{cm}$.

4. Tinggi dari tiga tinggkatan lemari, dengan ukuran $166 \mathrm{~cm}$, terdapat 9 loker. Sembilan loker inilah yang bisa naik-turun menggunakan sistem hidrolik.

5. Lintasan tangga bagian atas, yang terbuat dari besi. Dan mempunyai panjang keseluruhan 90 $\mathrm{cm}$.

6. Lintasan tangga bagian bawah, yang terbuat dari besi. Dan mempunyai panjang keseluruhan $120 \mathrm{~cm}$.

7. Ukuran tinggi keseluruhan loker $52 \mathrm{~cm}$.

Gambar 6. Desain Lemari Tampak Keseluruhan 


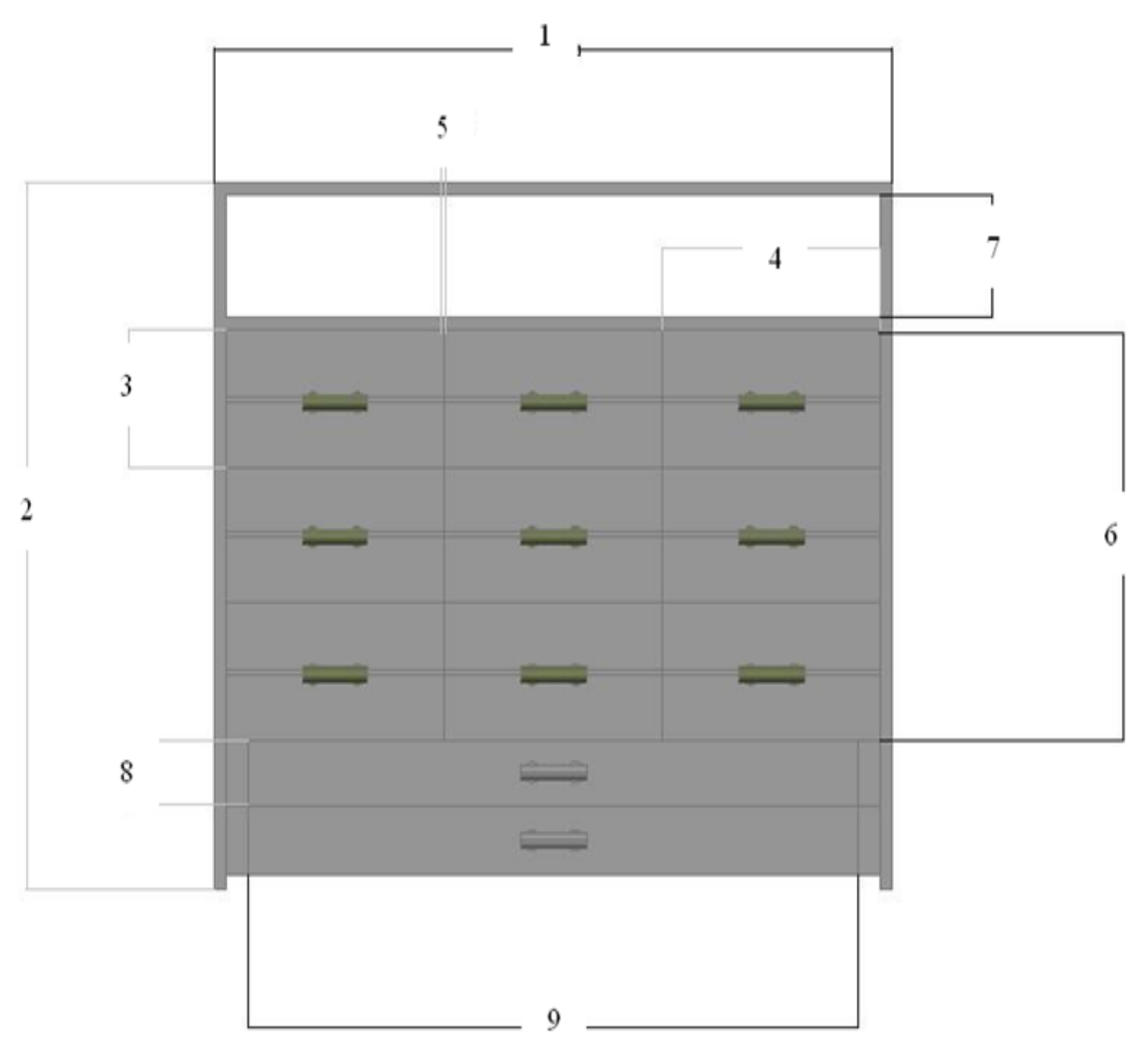

Gambar 18. Lemari Tampak Depan

\section{Keterangan :}

1. Ukuran lebar dari lemari, ukuran lebar yaitu $318 \mathrm{~cm}$.

2. Tkuran tinggi dari lemari, ukuran tinggi yaitu $304 \mathrm{~cm}$.

3. Ukuran tinggi loker, ukuran tinggi $52 \mathrm{~cm}$

4. Ukuran lebar loker, ukuran lebar yaitu $100 \mathrm{~cm}$.

5. Jarak dari setiap komponen, setiap komponen memiliki jarak masing-masing $2 \mathrm{~cm}$

6. Ukuran tiga tingkatan lemari, tiga tinggkatan lemari memiliki ukuran $162 \mathrm{~cm}$. Tiga tingkatan inilah yang bisa naik-turun.

7. Jarak bagian kosong dengan ukuran $60 \mathrm{~cm}$, yang berfungsi untuk jarak tiga tingkatan ters ebut naik-turun

8. Ukuran dari tangga, yaitu $25 \mathrm{~cm}$

9. Ukuran lebar tangga, yaitu $280 \mathrm{~cm}$

Gambar 7. Lemari Tampak Depan 

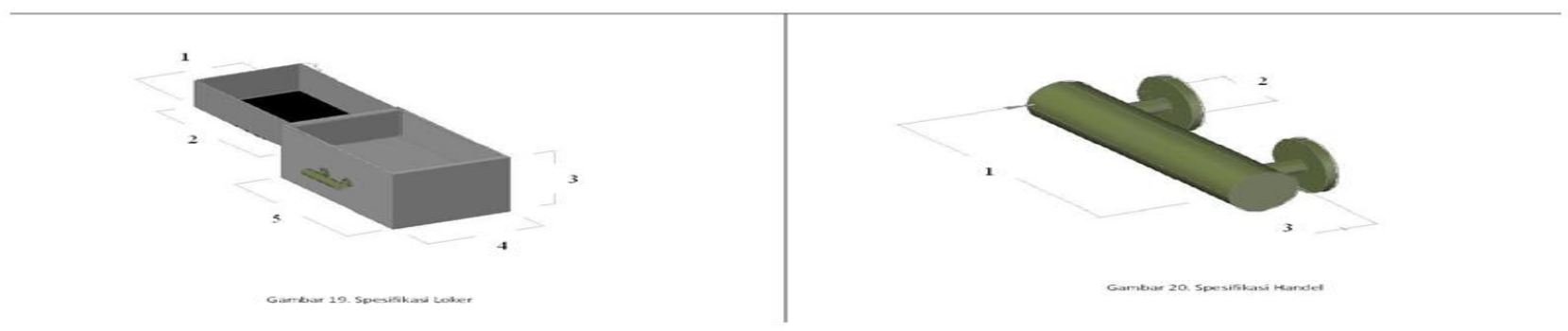

Keterangan

1. Ukuran kedal amannya adal ah $56 \mathrm{~cm}$.

2. Lebar dari 1 oker bagian atas, yang mempunyai 1 ebar $98 \mathrm{~cm}$

Tinggi keseluruhan dari 1oker yaitu $52 \mathrm{~cm}$.

4. Kedalam an dari $10 \mathrm{ker} 60 \mathrm{~cm}$

Lebar 10 ker $100 \mathrm{~cm}$.
Keterangan :

1. Ukuran Panjang Handel yaitu $30 \mathrm{~cm}$

2. Ukuran diameter pengait handel dan 1 emari $6 \mathrm{~cm}$.

3. Ukuran diameter handel $6 \mathrm{~cm}$.

Gambar 8. Ukuran Loker dan Handel

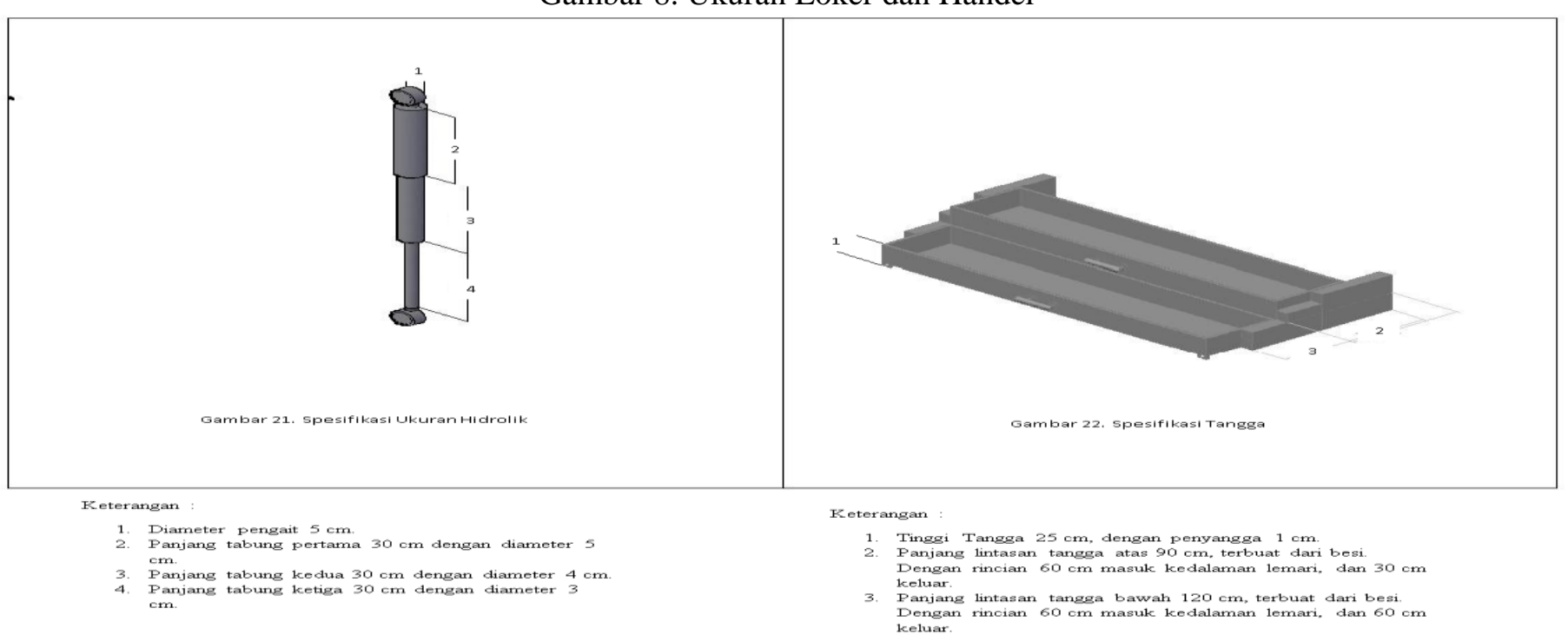

Gambar 9. Ukuran Hidrolik dan Tangga 


\section{KESIMPULAN}

Hasil desain lemari arsip di PT. Bank BRI Cabang Gombong (Tbk) Persero Menggunakan Metode Quality Function Deployment (QFD) sebagai berikut :

1. Spesifikasi desain lemari berdasarkan keinginan customeradalah : lemari mudah digunakan, lemari aman, lemari nyaman.

2. Lemari didesain sesuai dengan postur tubuh karyawan, jadi ketika digunakan lemari tersebut dapat mengurangi resiko cidera dalam pencarian.

3. Untuk memudahkan dan memaksimalkan pencarian terdapat sembilan kotak, agar lebih mudah masing-masing kotak telah dilengkapi adanya petunjuk sesuai dengan lokasi berkas (tambahan jika diperlukan) sesuai dengan pesanan untuk memudahkan dalam pencarian berkas nasabah. Kotak dapat digunakan dengan cara ditarik kedepan dan mempunyai 2 tingkatan untuk menampung lebih banyak berkas.

4. Terdapat 2 tangga yang dapat ditarik keluar untuk memudahkan pencarian berkas yang terdapat di bagian atas lemari. Serta lemari menggunakan sistem hidrolik pada sisinya untuk mengatur proses penggunaan dalam kondisi yang aman (ergonomis).

5. Bahan yang digunakan kayu jati agar produk awet dan kuat. Handel menggunakan kayu dengan diameter lima sampai enam cm diukur dari rata-rata genggaman tangan dan persentil 95,dan terdapat tambahan kunci. Bentuk lemari kotak sesuai dengan keinginan pengguna lemari tersebut.

\section{DAFTAR PUSTAKA}

[1] Anggraeni, Mutiara, Arie Desrianty, Yuniar, 2013, Rancangan Meja Dapur Multifungsi Menggunakan Quality Function Deployment (QFD), http://ejurnal.itenas.ac.id/ index.php/rekaintegra/article/view/231, diunduh pada 5 Oktober 2015 pukul 10.45.

[2] Arikunto, Suharsimi, 2006. Prosedur Penelitian Suatu Pendekatan Praktik, PT. Renika Cipta, Jakarta.

[3] Carolyn, M, Angelita, 2014, Usulan Perbaikan Desain Produk Lemari Praktis Menggunakan Quality Function Deployment (QFD),http:/library.gunadarma.ac.id/ repository/view/3783836/usulan-perbaikan-design-produk-lemari-praktis-

menggunakan-quality-function-deployment.html/, diunduh pada 19 November 2015 pukul 11.00.

[4] Ghozali,2011,Aplikasi Analisis Multivariate dengan ProgramIBM SPSS 19, Badan Penerbit Universitas Diponegoro, Semarang.

[5] Hidayako, A.F.N, 2015, Laporan Kerja Praktek Desain Perancangan Rak/Lemari Ergonomis, Sekolah Tinggi Teknologi Muhammadiyah Kebumen (Tidak Dipublikasikan).

[6] Ihsan, M Syaifudin, 2016, QFD (Quality Function Deployment), https://www.academia.edu /4995075/DIKTAT_KULIAH_REKAYASA_KUALITAS_TI-418_TOPIK _4_QFD _ QUALITY_FUNCTION_DEPLOYMENT_Diktat_ini_digunakan_bagi_mahasiswa_Jur usan_Teknik_Industri_Fakultas_Teknik_Universitas_Kristen_Maranatha_Disusun_oleh _JURUSAN_TEKNIK_INDUSTRI_FAKULTAS_TEKNIK, diunduh pada 1 maret 2016 pukul 11.00.

[7] Iswanti, Erna Zakiyah, 2015, Antropometri, Dimensi Dokumen rekam medis dan Sistem Penjajaran,Jurnal Rekam Medis, ISSN 1979-9551, VOL.IX.NO.1

[8] Jack B, Revelle, 1998, The Hand Book of QFD, NewYork : JohnWiley \& Sons, Inc.

[9] Mantondang, Zulkifli, 2016. Pengujian Homogenitas Varians Data. https://www.academia. edu/7698058/Pengujian_Homogenitas_Varians_Data, diunduh pada 19 april 2016 pukul 11.00

[10] Nurmianto, Eko,2003, Ergonomi Konsep Dasar dan Aplikasinya, Edisi Pertama, GunaWidya, Jakarta, 
[11] Negara, Humaira Abu, 2012,Antropometri, http://www.academia.edu/5358148/ Antropometri, diunduh pada 10 Maret 2015 pukul 11.30

[12] Sugiyono, 2010,Metode penelitian pendidikan, Alfabeta, Bandung.

[13] Sugiyono, 2010,Statistika untuk Penelitian, Alfabeta, Bandung.

[14] Sulianta, Feri, 2010,IT Ergonomics, PT. Elex Media Komputindo, Jakarta.

[15] Wignjosubroto Sritomo, 2000, Ergonomi Studi Gerak dan Waktu, Teknik Analisis untuk Peningkatan Produktivitas Kerja, Jakarta

[16] Xeno, Indra, 2015, QFD (Quality Function Deployment), http://www.academia.edu/ 9376419/QFD, diunduh pada 30 September pukul 11.30 